\section{THU0058 APOPTOSIS, SEX HORMONES AND ADENOSINE DEAMINASE LEVELS IN CULTURED MONOCYTES (THP-1 CELLS) AND SYNOVIAL RHEUMATOID MACROPHAGES TREATED WITH METHOTREXATE}

ME Cutolo, B Villaggio, A Sulli, A Bisso, C Pizzorni, M Briata, M Grosso, C Prete, L Felli, B Seriolo. Department Internal Medicine Division Rheumatology, University of Genova, Genova, Italy

\subsection{6/annrheumdis-2001.902}

Background Both testosterone (T) and methotrexate (MTX) seem to exert negative effects on cell growth that might partially explain some of their antiproliferative/antiinflammatory effects exerted in rheumatoid arthritis (RA). ${ }^{1,2}$

Objectives Therefore, we evaluated the T and MTX effects on cell apoptosis (apo) in cultured human myeloid monocytic cells (THP-1) differentiating into macrophages (M) and in cultured synovial M obtained from RA patients. Since extracellular adenosine increase seems implicated in the MTX action, we evaluated also the enzyme adenosine deaminase (ADA) levels. ADA is involved in adenosine metabolism.

Methods Synovial RA M as well as the THP-1 cells induced to differentiate into $M$ (IFN gamma 500U), were cultured in presence of $\mathrm{T}(10-8 \mathrm{M})$ and 17-beta estradiol (E2,10-8M) alone. The cells were also treated with the MTX concentrations present in vivo during RA therapy $(=50 \mathrm{microg} / \mathrm{ml})$ again alone, or in association with T plus MTX or E2 plus MTX. After $24 \mathrm{~h}$ early and late apo were evaluated by immunofluorescence (annexin V and propidium iodide assay, respectively). ADA was evaluated on supernatants by spectrophotometry.

Results By considering the THP-1 cells, a significant induction of the late apo in T (17\%) (p less 0.05), MTX (80\%) alone, and T (72\%), E2 (74\%) plus MTX-treated cells was observed (all p < 0.001). No significant differences were observed during the early apo for all the treatments during the $24 \mathrm{hr}$. By evaluating the RA synovial $\mathrm{M}$, a significant $(\mathrm{p}<0.001)$ induction of the late apo $(50 \%)$ was observed in the T plus MTX-treated M when compared with the alone MTX- or E2-treated M. The treatment of RA $\mathrm{M}$ with $\mathrm{T}$ alone was found to induce an evident cell apo (30\%) (although non significant). ADA levels increased only in the supernatants from all the MTX-treated cells vs MTXuntreated controls, mainly in THP-1 cells.

Conclusion The $\mathrm{T}$ and MTX-induced apoptotic effects were more evident in cultured THP-1 cells than in cultured RA M. Therefore, immature differentiating monocytes (i.e. infiltrating monocytes) seem more sensible to the pharmacologic effects of MTX than differentiated cells (i.e. resident $M$ ). The significant increase of ADA levels found only in MTX-treated cells, might support the already suggested implication of adenosine level increase as part of the pharmacologic effects exerted by MTX.

\section{REFERENCES}

1 Cutolo M, Wilder R. Rheum Dis Clin North Am. 2000;26:825

2 Cutolo M, et al. J Rheumatol. 2000;27:2551

\section{THU0059 INTEGRATIVE APPROACH TO STUDY OF IMMUNE RESPONSE TO CERULOPLASMIN IN RHEUMATIC DISEASES}

EA Sushchuk, NV Petrova, IP Gontar, AB Zborovskiy. Laboratory of Immunology, Scientific Research Institute for Clinical and Experimental Rheumatology of RAMS, Volgograd, Russia
Background Ceruloplasmin (CP) is a multi-copper oxidase with incompletely determined biological functions. It plays a role in acute phase response, has free-radical scavenger properties, antibodies $(\mathrm{AB})$ to $\mathrm{CP}$ in some connective tissue diseases have been reported.

Objectives To determine changes in $\mathrm{CP}$ activity and levels in serum, and detect $\mathrm{AB}$ to $\mathrm{CP}$ in rheumatoid arthritis (RA) and systemic lupus erythematosus (SLE) patients.

Methods Serum levels of immunoreactive CP (by commercial ELISA test), oxidase activity of the CP, as well as the specific oxidase activity (enzyme activity per unit of mass) were measured in 76 RA patients (49 female and 27 male) and in 56 SLE patients (96\% female) at admittance to hospital and two weeks later. Patients were examined by clinical, laboratory, immunological and radiographic methods, diagnosis was established according to American College of Rheumatology criteria for RA (1987) and SLE (1997). Antibodies to CP were detected using custom developed ELISA method. Antibody binding was considered positive, when optical density readings were above 2 standard deviations of all normal human sera, 46 healthy donors served as a control group.

Results Serum levels of CP, oxidase activity and specific oxidase activity were significantly higher in the group of RA and SLE patients than in the control group $(p<0.05)$. Increase in oxidase activity and CP levels were more prominent in RA patients with moderate and maximum disease activity, compared with minimal activity of disease $(\mathrm{p}<0.001)$ and correlated with SLEDAI score in SLE. Antibodies to CP were detected in 78\% of RA patients with visceral involvement and in $43 \%$ of patients without visceral lesions. In SLE patients $\mathrm{AB}$ to $\mathrm{CP}$ were detected in $46 \%$. Specific oxidase activity of CP was significantly lower in patients with presence of $\mathrm{AB}$ to $\mathrm{CP}$ compared to patients with no $A B$ to $C P$ in serum $(p<0.05)$. After 2 weeks of treatment decrease in serum levels of $\mathrm{CP}$ and oxidase activity was observed, correlating with decrease in levels of non-specific markers of inflammation (C-reactive protein, ESR). Decrease in specific oxidase activity of $\mathrm{CP}$ in patients without $\mathrm{AB}$ to $\mathrm{CP}$ in serum was statistically significant $(\mathrm{p}<0.001)$, while no or insignificant decrease was observed in the group of patients with $A B$ to CP. After 2 weeks of treatment the proportion of patients, having $\mathrm{AB}$ to $\mathrm{CP}$ reduced, but the reduction was statistically insignificant. Specific oxidase activity was more sensitive indicator of active inflammation in these diseases than levels of CP in serum or $\mathrm{CP}$ oxidase activity in patients without $\mathrm{AB}$ to $\mathrm{CP}$, but this sensitivity was diminished in presence of $\mathrm{AB}$ to $\mathrm{CP}$.

Conclusion Antibodies to CP were detected in serum of RA and SLE patients, capable of decreasing oxidase activity of CP, thus leading to diminished specific oxidase activity in such patients. Since oxidase activity of CP in essential for its antioxidant properties, these $\mathrm{AB}$ to $\mathrm{CP}$ can play an important role in free-radical tissue injury in rheumatic diseases. Levels of CP in serum and oxidase activity of CP can be used as markers of inflammation in RA and SLE.

\section{THU0060 SERUM YKL-40 IN RHEUMATOID ARTHRITIS: CLINICAL CORRELATIONS}

M Carrabba, M Chevallard, E Torchiana, PC Sarzi Puttini, S Santandrea, L Boccassini, M Antivalle, G Santalena, MG Marrazza. Rheumatology Unit, Luigi Sacco University Hospital, Milan, Italy

10.1136/annrheumdis-2001.904 
Background YKL-40 or gpl-39 is a surface glycoprotein of connective tissue cells in particular of monocytes, fibroblasts, synoviocytes and chondrocytes. According to some Authors, being augmented in serum of rheumatoid arthritis (RA) and, to a lesser extent, of osteoarthritis (OA) it may correlate with the degree and the speed of cartilage degradation.

Objectives To better evaluate if this is true or if this marker is mainly an inflammation index, we have investigated a group of RA patients correlating YKL-40 serum values with some of the clinical parameters of the disease most widely used in literature (swollen or painful joint count, HAQ, PCR, Ra-test, ESR, Rx score of the hands, DAS 28).

Methods We have evaluated 52 consecutive patients (43 F, 9 M) with RA according to the ACR criteria mainly in the 2nd (22) or 3rd (25) functional class of Steinbrocker. Their mean age was 59.7 years (33-86) and the mean disease duration 13.6 years (135). The YKL-40 was determined in serum according to the ELISA sandwich method of Harvey et al, 1998 (normal range: 25-95 $\mathrm{ng} \backslash \mathrm{ml}$ ); all the patients (pts) were previously visited and all the parameters listed above measured. Moreover the Rx score of the hands was calculate according to the method of Kaye, 1987, slightly modified. The significance of the correlations were evaluated with the Spearman test.

Results The mean $( \pm$ SD) serum values of YKL-40 was 147.84 ( \pm 97.47) $\mathrm{ng} \backslash \mathrm{ml}$ (normal range: $25-95 \mathrm{ng} \backslash \mathrm{ml}$ ). The correlations with the parameters listed above were those shown in the following Table 1. Swollen joint count, $\mathrm{Rx}$ score and Ra-test showed a still less significant correlation with the marker investigated.

\begin{tabular}{lll} 
Abstract THU0060 Table 1 & & \\
\hline & $\mathbf{r}$ & $\mathbf{p}$ \\
\hline PCR & 0.531 & $<0.001$ \\
DAS 28 & 0.358 & $=0.010$ \\
PAINFUL JOINT COUNT & 0.322 & $=0.020$ \\
HAQ & 0.260 & $=0.056$ \\
ESR & 0.243 & $=0.083$ \\
\hline
\end{tabular}

Conclusion Since YKL-40 in RA serum seems to better correlate with PCR, DAS 28 and painful joint count respectively, in our opinion it behaves more like an activity marker of the disease (perhaps of synovitis) rather than of cartilage degradation as claimed by some Authors. Despite this limitation, further studies are needed to evaluate its potential prognostic activity as predictor of joint lesions in RA.

\section{REFERENCES}

1 Harvey $S$, et al. Chondrex: a new marker of joint disease. Clin Chem. 1998:44:509-16

2 Wollheim FA. Markers of disease in RA. Curr Opin Rheumatol. 2000;12:200-4

\section{THU0061 RIBOSOMAL P PROTEIN ANTIBODIES}

SM Ivanova, GG Karpova, NV Bogachiova, TA Riazantctva, Al Speranskey. Department of Clinical Immunology, Institute of Rheumatology, Moscow, Russia

\subsection{6/annrheumdis-2001.905}

Background Circulating autoantibodies are one of the main characteristic of autoimmune disease as systemic lupus erythematosus (SLE). The associations between anti-DNA antibodies and renal disease, anti-Ro with cutaneous manifestations and congenital heart block are well established. The human ribosomal $\mathrm{P}$ proteins (RPP) designated PO (38 kd), P1 (19 kd), and P2 (17 kd), the clinical significance of these antibodies is disputed, but some data suggest an association with aggressive disease, nephritis, central nervous system (CNS) abnormalities.

Objectives The aim of the present study was to determine the possible clinical and immunological associations of anti-RPP antobodies in SLE.

Methods Serum samples from 68 patients with SLE who satisfied the American Rheumatism Association revised criteria for SLE entered the study. Anti-RPP activity was determined by ELISA (TRINITY BIOTECH RIBOSOMAL P $1 \mathrm{gG}, \mathrm{A}, \mathrm{M}$ ), the specifity was confirmed by Western blotting (Wb). Antinuclear factor (ANF) was detected by indirect immunofluorescence, anti-DNA by ELISA, anti-Ro, La, RNP, Sm antibodies -by double immunodiffusion, CRP, C3, C4-by radial immunodiffusion.

Results Anti-RPP antibodies were demonstrated by ELISA in sera of 13 patients (19\%). 17 sera were investigated by Wb, 6 of them were positive by both ELISA and $\mathrm{Wb}$, another 11 were negative as in ELISA, as in $\mathrm{Wb}$. Anti-P reactivity was against 38 $\mathrm{kd}(\mathrm{P} 0), 19 \mathrm{kd}(\mathrm{P} 1)$ and $17 \mathrm{kd}(\mathrm{P} 2)$ in one sera; $38 \mathrm{kd}$ and 17 $\mathrm{kd}$ (PO, P 2) in 4 sera; and $38 \mathrm{kd}$ (PO) also in one sera. SLEDAI score was $13,6+8,65$ in seropositive group, and $16,7+25,82$ in seronegative. The frequency of nephritis, CNS involvement was significantly higher in RPP-positive patients-38,5\% (5/13) and $38,5 \%(5 / 13)$ against 7,3\% (4/55) and 18\%(10/55). In the group of 15 SLE patients with CNS involvement 5 (33\%) had increased anti-RPP antibody levels. The highest levels of antiRPP had 3 patients with agressive disease, all of them had nephritis, one also psychosis-convulsions, and one-hemolytic anaemia. Conclusion In conclusion, we suggest that anti-RPP antibodies may be a good serological marker for not only SLE, but for aggressive duration of disease, including damaging of kidney and brain.

(abstract for oral presentation).

\section{THU0062 ASSESSING INFLAMMATORY ACTIVITY IN RHEUMATOID ARTHRITIS AND ANKYLOSING SPONDYLITIS. SERUM AMYLOID A OR C-REACTIVE PROTEIN?}

${ }^{1} A$ Gómez, ${ }^{1} \mathrm{R}$ Sanmartí, ${ }^{2} \mathrm{~L}$ Álvarez, ${ }^{1} \mathrm{G}$ Salvador, ${ }^{1} \mathrm{JD}$ Cañete, ${ }^{2} \mathrm{X}$ Filella, ${ }^{1} \mathrm{~J}$ Gratacós, 1J Muñoz-Gómez. ${ }^{1}$ Rheumatology; ${ }^{2}$ Biochemistry, Hospital Clinic, Barcelona, Spain

\subsection{6/annrheumdis-2001.906}

Background Serum amyloid A (SAA) protein has been suggested to be a more sensitive marker of disease activity than CRP in rheumatoid arthritis (RA). Few studies are carried out in patients with ankylosing spondylitis (AS).

Objectives To analyse if SAA correlates with other markers of inflammatory activity such as CRP, ESR and serum levels of IL-6 in both RA and AS. To evaluate if SAA is the most sensitive marker of clinical disease activity in RA.

Methods Using a sensitive ELISA test (N-latex SA, Dadde Behring), SAA was measured in the serum of 51 patients with RA and 44 patients with AS. CRP, ESR and serum IL-6 (ELISA) were measured simultaneously. Clinical parameters of disease activity (number of painful and swollen joints) and Thompson's articular index were analysed also in RA patients.

Results The magnitude of the SSA response was greater than the $\mathrm{CRP}(\mathrm{x} \pm \mathrm{SD}: \mathrm{SAA}=32.7 \pm 56.7 \mathrm{mg} / \mathrm{l}$ vs $\mathrm{CRP}=18.8 \pm 26.3$ $\mathrm{mg} / \mathrm{l} \mathrm{p}<0.001)$. Patients with RA showed higher SAA levels than AS $(\mathrm{x} \pm \mathrm{SD}: 44.8 \pm 64 \mathrm{mg} / \mathrm{l}$ vs $13.6 \pm 18.9 \mathrm{mg} / \mathrm{l} \mathrm{p}<$ 